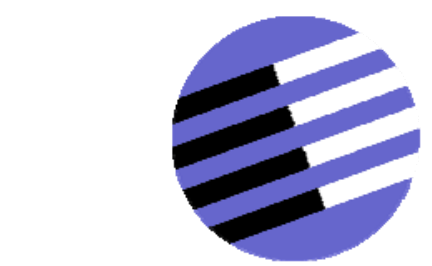

GOVERNANCE AND THE EFFICIENCY

OF ECONOMIC SYSTEMS

GESY

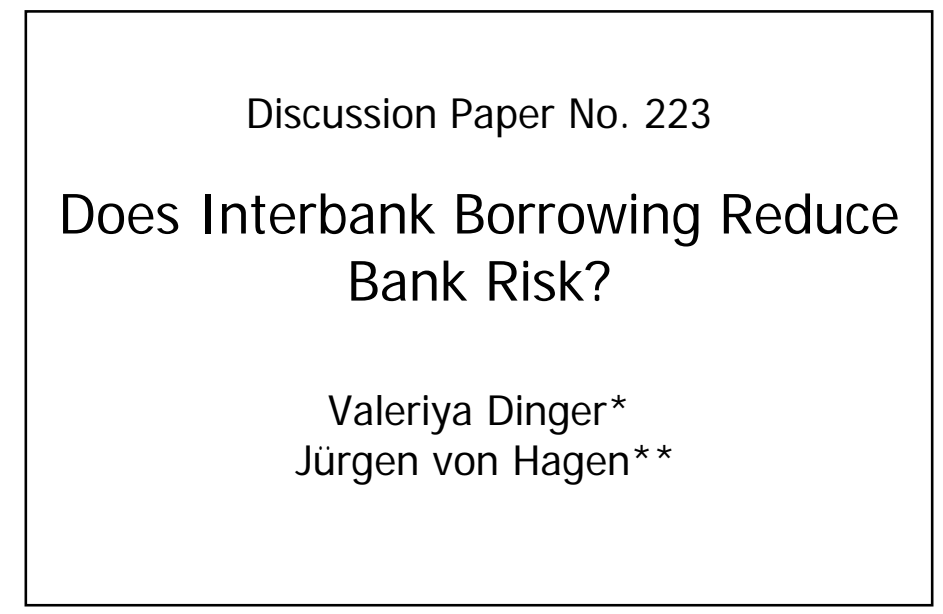

November 2007

*Valeriya Dinger, University of Bonn, valeriya.dinger@uni-bonn.de

**J ürgen von Hagen, University of Bonn, Zentrum für Europäische Integrationsforschung 53113 Bonn, Germany

Tel.: +49-228-73-9199, Fax: +49-228-73-1809

vonhagen@uni-bonn.de

Financial support from the Deutsche Forschungsgemeinschaft through SFB/TR 15 is gratefully acknowledged.

Sonderforschungsbereich/Transregio $15 \cdot$ www.gesy.uni-mannheim.de

Universität Mannheim · Freie Universität Berlin · Humboldt-Universität zu Berlin · Ludwig-Maximilians-Universität München Rheinische Friedrich-Wilhelms-Universität Bonn · Zentrum für Europäische Wirtschaftsforschung Mannheim 


\title{
Does Interbank Borrowing Reduce Bank Risk?
}

\author{
Valeriya Dinger* and Jürgen von Hagen ${ }^{* *}$
}

November $2007^{a}$

\begin{abstract}
:
In this paper we investigate whether banks that borrow from other banks have lower risk levels. We concentrate on a large sample of Central and Eastern European banks which allows us to explore the impact of interbank lending when exposures are long-term and interbank borrowers are small banks. The results of the empirical analysis generally confirm the hypothesis that long-term interbank exposures result in lower risk of the borrowing banks.
\end{abstract}

Key words: interbank market, bank risk, market discipline, transition countries

JEL: G21, E53

\footnotetext{
${ }^{a}$ We thank an anonymous referee, Adam Ashcraft, Hendrik Hakenes, Iftekhar Hasan, Deborah Lucas and Erik Theissen and participants at XII Tor Vergata Conference on Money and Banking -2003, the Far Eastern Meeting of the Econometric Society -2004 and the Verein für Socialpolitik Tagung - 2004 for valuable comments on earlier drafts.
}

Valeriya Dinger is postdoc at the University of Bonn (E-mail: valeriya.dinger@uni-bonn.de). Jürgen von Hagen is professor of economics at the University of Bonn and research fellow at CEPR, London (E-mail: vonhagen@uni-bonn.de). 


\section{Introduction}

Policy makers have shown considerable interest in market discipline as a supplement to bank regulation. The idea is that regulators can use market signals to identify banks which the market perceives as riskier (Berger, 1991). ${ }^{1}$ Most of the "market discipline" literature has concentrated on using traded subordinated debt and equity pricing as a market discipline tool (Morgan and Stiroh, 2001; Sironi, 2002; Evanoff and Wall, 2002; and Ashcraft, forthcoming). In this paper we take another approach in concentrating on interbank borrowing as a signal of risk.

Interbank exposures have often been viewed in the literature as a source of contagion (Allen and Gale, 2000 and Freixas, Parigi and Rochet, 2000) and, therefore, as a factor enhancing systemic risk. However, Rochet and Tirole (1996) argue that, by generating incentives for lending banks to monitor interbank-borrowing banks, interbank exposures may also contribute to prudent market behavior and reduce the risk of bank failures and systemic distress. The idea is that banks are particularly good at identifying the risks of other banks (Calomiris, 1998). Provided with proper incentives, they can perform a complementary task to bank regulation and supervision by the authorities.

Despite the obvious appeal of this idea, empirical research on the issue is limited. In a first step in this direction, Furfine (2001) examines the pricing of interbank lending agreements as an indicator of the ability of banks to monitor their interbank borrowers. Since interbank loans in the federal funds market are large and uncollateralized, they expose lending institutions to significant credit risk. Lending banks, therefore, have an incentive to monitor their counterparties and price these loans as a function of the credit risk of the borrowing bank. ${ }^{2}$ Furfine's empirical results support this hypothesis by showing that borrowing banks with higher profitability, higher capital ratios, and fewer problem loans pay lower interest on

\footnotetext{
${ }^{1}$ See Flannery and Nikolova (2004) for a detailed overview of the market discipline literature.

${ }^{2}$ In a strict sense Furfine (2001) studies screening of the borrowing banks' risk (prior to the lending) rather than monitoring by the lending banks.
} 
federal fund loans than others. However, the impact is fairly small; for example, a one standard deviation rise in the loan-to-capital ratio raises the interest rate by merely 1.5 basis points. In a more recent paper, King (forthcoming) also finds that high-risk banks pay higher interest on federal funds. He shows, in addition, that more risky banks will borrow less in the federal funds market. Ashcraft and Bleakley (2006) point to the fact that the studies focusing on the correlation of prices with risk may confound supply and demand effects. To disentangle supply and demand effects they use exogenous shocks to a bank's liquidity position to trace out the credit supply curve. Using this approach, they document only weak evidence of the existence of market discipline.

A potential reason for the small economic significance of the results and the low empirical research interest in the issue is that the economic analysis of interbank exposures has so far concentrated on highly developed banking markets, where interbank exposures are mostly generated by short-term liquidity needs (as modeled by Bhattacharya and Gale, 1987). As pointed out by Rochet and Tirole (1996), short-term interbank exposures might not be effective disciplinary tools since they can quickly be abandoned by both the borrowing and the lending banks. Furthermore, in an environment where interbank borrowers are large institutions the disciplining role of interbank borrowing may be hampered by too-big-to-fail concerns, since the interbank lenders anticipate potential bail-outs of the large interbank borrowers.

Our purpose in this paper is to document that interbank borrowing is associated with lower risk-taking of borrowing banks. This phenomenon would be consistent with the market discipline hypotheses and with some type of monitoring role performed by the lending banks.

To empirically test this hypothesis we employ data from a sample of Central and Eastern European (CEE) countries, where interbank trade is the result of long-term specialization of incumbent banks in issuing deposits and of new entrant banks in lending to nonbanks. We define banking systems with such a structure as two-tier banking systems. Two-tier banking systems present two advantages for the analysis of the risk alleviating role of interbank 
borrowing. First, in this environment, interbank lending is characterized by longer maturities than those common in the US, where interbank loans are usually overnight. ${ }^{3}$ Second, interbank borrowing banks are typically small institutions. Therefore, in this context the toobig-to-fail doctrine does not apply for the interbank borrowers and interbank lenders are likely to react to the observed risk of the borrowing bank without counting on being bailed out.

The rest of the paper is structured as follows. Section 2 describes the emergence and the characteristics of the two-tier banking systems in CEE countries. Section 3 presents a short discussion on the relationship between interbank borrowing and bank risk. Section 4 introduces the data sources. Section 5 presents the empirical analysis and section 6 concludes.

\section{Bank specialization and interbank borrowing in CEE}

We consider banks from ten Central and Eastern European (CEE) countries with a common past of planned economies. Before we proceed with the empirical analysis, we will present a short overview of the CEE banking market developments which led to the emergence of twotier banking structures in some of these countries.

The two-tier banking system structure is characterized by high volumes of interbank borrowing from the largest banks, which dominate the deposit markets, by the smaller banks, which together dominate the market for loans to nonbanks. It emerged only in some of the sample countries (Czech Republic, Hungary, Poland and Slovakia). In other sample countries (Estonia, Latvia, Lithuania, Romania and Slovenia) new entrant banks dominate both the deposit and the loan market and we observe a classical banking system structure with banks active in both the deposit and the loan market. We include banks from countries with classical banking system structures in order to control for other transition specific effects.

\footnotetext{
${ }^{3}$ Although the role of specialization as a cause of interbank trade has not yet been studied thoroughly, some studies indicate that it is a valid explanation for the very high intensity of interbank trade in countries with relatively underdeveloped financial systems. See e.g. Galmes and Manzano (1995) for the Spanish banking system, Cole and Slade (1996) for Indonesia, and Bonin et al (1998) for several Central and Eastern European (CEE) transition economies.
} 
The emergence of the two-tier systems was mainly a result of the design of banking system reforms. It emerged in those countries where governments were unwilling to let incumbent banks fail and undertook massive and repeated recapitalization programs. In the early transition period no explicit deposit insurance schemes existed, but the repeated recapitalization of the incumbent banks provided an implicit deposit guarantee on incumbents' deposits. At the same time, small new entrants were allowed to fail ${ }^{4}$. In the meantime the pool of borrowers rapidly changed in these economies, with the share of small and medium-sized enterprises constantly increasing. The new banks seemed to be better suited to lend to the small private businesses than the large incumbent banks. ${ }^{5}$ As a result, the new entrant banks had a large demand for loans but insufficient customer deposits to finance them, while the incumbents held customer deposits in excess of loan commitments. This was the pattern of banking system transition in Bulgaria (only in the early transition period), the Czech Republic, Hungary, Poland and Slovakia. In Hungary, for example, the largest incumbent bank, OTP, held 55\% of all deposits in 1994 but only 31\% of all loans. By 2004 the figures had changed to $26 \%$ of all deposits and $16 \%$ of all loans. Similarly, in the Czech Republic, Sporitelna Banka held 39\% of all deposits in 1994 but only $18 \%$ of all loans; by 2004 the deposit market share of Sporitelna Banka had declined to 26\%, while its loan market share stayed almost constant at $20 \%$.

A different scenario developed in the Baltic countries, where the incumbents, inherited from the Soviet era, were Baltic branches of Soviet banks. Some of these banks were partially acquired by private Russian enterprises as their parent banks went through an ownership transformation. This gave the governments of the newly independent countries an easier political platform to liquidate the troubled banks instead of recapitalizing them (Bonin et al, 1998). With no incumbents to protect, banking system development started from scratch after

\footnotetext{
${ }^{4}$ Explicit deposit insurance schemes covering all banks were introduced in all CEE countries only in the late 1990s. Deposits are insured up to certain thresholds which vary across the countries between 2500 and 20000 Euro (Nenovsky and Dimitrova, 2003). However, the credibility of these new schemes has not yet been tested as no formal bank failure has occurred since then.

${ }^{5}$ The fact that small banks have competitive advantages in serving small borrowers has been well established in the banking literature (Stein, 2002 and Berger et al, 2005).
} 
the wide-spread banking crisis in the Baltics of 1994-95. New institutions, mostly subsidiaries of foreign banks (e.g. Hansa bank), emerged and quickly acquired large market shares in both the deposit and the loan market.

To illustrate the features of the two-tier banking systems we construct two variables which measure the transfer of funds from institutions dominating the deposit market to the rest of the banks. First, we define as large those banks that, in a given year and country, have a market share of at least $20 \%$ in the market for customer deposits. The rest of the banks in each country are defined as small. We then measure the transfer of funds by two ratios: the ratio of large banks' net interbank assets to customer deposits $\left(\mathrm{NIA}_{\mathrm{lb}} / \mathrm{CD}_{\mathrm{lb}}\right)$ and the ratio of small banks' net interbank position to their loans $\left(\mathrm{NIA}_{\mathrm{sb}} / \mathrm{L}_{\mathrm{sb}}\right) .{ }^{6}$ Tables 2 and 3 illustrate the values of these ratios for each of the sample countries. As the data in these tables illustrate, up to $50 \%$ of the deposits of the largest banks in the Czech Republic were channeled through the interbank market. For Hungary, Poland and Slovakia that number is about 20\%. ${ }^{7}$ Small banks in these countries financed up to $20-30 \%$ of their loans through interbank borrowing. It is important to notice here that a very large share of the interbank exposures were with a maturity of over 3 months. ${ }^{8}$

\footnotetext{
${ }^{6}$ Alternatively as a robustness check we have tried a "large" bank identification methodology based on the number of banks in the respective country. We define as "large" the 5\% largest (in terms of customer deposits) banks in a country (so countries with up to 20 banks have 1 "large bank, in countries with up to 40 banks we define 2 "large" banks and in such with up to 60 bank we define 3 "large" banks. The use of this alternative definition of "large" banks only slightly changes the values of the transfer of funds variables (NIA_SB and NIA_LB). The results of the regressions do not change qualitatively either. We also tried defining the $10 \%$ largest (in terms of customer deposits) banks in a country as "large" banks. In this case, however, we encounter the problem of dealing with a too unstable sample of "large" banks. In the case of Poland, for example, we have to identify in each of the years 1995-2004 the 6 largest banks in terms of customer deposits. Whereas the sample of the top two banks stays unchanged throughout the period ( $P K O B P$, and Bank Pekao), different banks occupy the third to sixth place in different years, with banks like Bank Handlowy w Warszawie and Bank Millenium repeatedly exiting and entering the "large" banks sample. We choose not to pursue this approach of identifying the large banks since we want to concentrate on a stable sample.

${ }^{7}$ As indicated by the negative values in Table 2 large banks in one-tier systems are often net borrowers of interbank funds, similarly the positive values in Table 3 indicate that one-tier systems' small banks are often net interbank lenders.
}

${ }^{8}$ Bonin et al (1998) 


\section{Interbank borrowing and bank risk}

The incumbent banks in two-tier banking systems have well established deposit gathering networks and in addition enjoy implicit government deposit guarantees. As a result, they are able to accumulate retail deposits at lower costs than the new entrants, which lack a developed deposit gathering network and government protection. They can, therefore, provide interbank loans to these new entrant banks at interest rates lower than the rates the new entrants would have to pay in the deposit market. ${ }^{9}$ New entrants that do not borrow from the incumbents have to offer substantially higher deposit rates than the incumbents not only as a risk premium but also to compensate their customers for any switching costs and the inconveniencies resulting from the worse geographical coverage.

The two-tier banking systems described above provide a good setting for testing the hypothesis that interbank borrowers are less risky. The empirical analysis that follows focuses on the question whether the loan portfolios of interbank-borrowing banks are characterized by lower levels of risk than banks which do not borrow in the interbank market. We address this issue by regressing different measures of bank risk on a measure of a bank's interbank borrowing position. Since interbank borrowing may be endogenous with respect to bank risk, we present alternative identification approaches based on instrumental variables.

Finding, as we do below, that banks that depend on interbank borrowing have systematically lower risk levels is consistent with a market-discipline argument. The same empirical finding could arise, however, if the lending banks were risk averse and lent only to banks whose risk levels happen to be relatively low. Nevertheless, such a portfolio selection effect still requires that the lending banks have information about the borrowing banks. If such information is not available publicly, the lending banks, as in the market-discipline argument, would have to invest in information about the borrowing banks, and their actions can therefore be informative to regulators.

\footnotetext{
${ }^{9}$ In Dinger and von Hagen (2005) we explicitly model why incumbents prefer extending interbank loans to operating in the credit market.
} 


\section{Data}

We match data from the following sources. Macro level variables are obtained from the International Financial Statistics CD-ROM issues by the IMF. Micro level data are obtained from banks' financial statements provided by BankScope. ${ }^{10}$ Our sample includes 296 banks, of which 28 are Bulgarian, 35 Czech, 12 Estonian, 36 Hungarian, 28 Latvian, 14 Lithuanian, 56 Polish, 34 Romanian, 24 Slovakian, and 29 Slovenian. In each of the sample countries, BankScope covers $70-90 \%$ of the banks calculated as percentage of banking assets. We have restricted the analysis to the period of 1995-2004. We avoid the use of data from the restructuring and recapitalizing period 1990-1994 which are quite noisy. Data for some of the banks are available for only some of the years, which results in an unbalanced panel dataset. Table 4 provides summary statistics of some key variables.

We perform the regressions on a sample consisting only of the banks that are regarded as small by the construction of the transfer of funds variables, since the creditors of large banks may be less concerned with their borrowers risk because of too-big-to-fail considerations. However, results do not qualitatively change if the estimations are performed using the full sample of banks.

\section{Comparison of banks' risk characteristics: empirical evidence}

In this section we provide an empirical test of the relation between interbank borrowing and bank risk.

Our primary interest is in estimating an equation of the following form:

$$
B R_{i j t}=\beta_{1}+\beta_{2} * I P_{i j t}+\beta_{3} * X_{i j t}+\beta_{4} * Y_{j t}+\beta_{5} * C_{j}+\beta_{6} * T_{t}+\varepsilon_{i j t},
$$

where $B R_{i j t}$ denotes a measure of the risk incurred by bank i in country $\mathrm{j}$ at time $\mathrm{t}, I P_{i j t}$ is the interbank position of bank $\mathrm{i}$ in country $\mathrm{j}$ in time $\mathrm{t}, X_{i j t}$ is a vector of control variables at the

\footnotetext{
${ }^{10}$ BankScope is a database created by IBCA and Bureau van Dijk.
} 
level of the individual bank, $Y_{j t}$ is a vector of control variables at the level of country of operations, $C_{j}$ and $T_{t}$ are vectors of country and year dummies, and $\varepsilon_{i j t}$ is the error term.

To measure the riskiness of a bank's business ${ }^{11}$ we use three variables that have been widely used in the literature: loan-loss reserves to gross loans $(L L R)$, loan-loss provisions to gross loans $(L L P)$ and the ratio of net charge-offs to equity $(N C O) .{ }^{12,13}$

To measure the impact of interbank borrowing on bank risk, we include as an explanatory variable the net interbank position of a bank measured by the ratio of net interbank assets to total assets $(N I A / T A) .{ }^{14}$ If this ratio has negative values, the bank is a net borrower in the interbank market. Positive values of the ratio indicate that the bank is a net provider of interbank funds. ${ }^{15}$

Several control variables are included in the estimation. At the individual bank level, we introduce bank size, capitalization level, and foreign ownership as control variables. We represent a bank's size by the logarithm of total assets. In addition, we use the squared bank size term to allow for a non-linear form of the dependence between bank size and risk undertaking. Capitalization is measured by the ratio of equity to total assets. Foreign ownership is captured by a dummy variable equal to one if at least $50 \%$ of a bank's equity is owned by an institution based abroad and to 0 otherwise. We include this variable to account for the possibility that foreign-owned banks have a better technology for assessment of credit worthiness and are thus less likely to generate non-performing loans.

\footnotetext{
${ }^{11}$ See Martin (1977) and Gonzales-Hermosillo, et al (1996).

12 The use of more sophisticated market based measures of bank risk, e.g. interest rate on certificates of deposits, bank bond prices, etc., is not possible for the sample of CEE banks since such instruments were not used in most of the CEE countries during the period we study.

${ }^{13}$ All three risk measures are in logarithmic form.

${ }^{14}$ We use the continuous variable instead of an "interbank borrowing" dummy to control for the fact that monitoring incentives of the lender are increasing with the amount of interbank borrowing (as discussed in Section 3).

${ }^{15}$ As a robustness check we have performed the estimation using the ratio of a bank's interbank liabilities to total assets as a proxy for a bank's interbank position. The results (which are available from the authors upon request) do not differ qualitatively from the results using the net interbank assets to total assets ratio.
} 
At the country level we include the following macroeconomic variables as controls: inflation, per capita GDP, and the growth rate of GDP. Inflation is defined as the percentage change in the GDP deflator. Per capita GDP is used as a general index of economic development and is measured in thousands of US dollars. GDP growth is used to measure cyclical effects on bank risk and is measured as the percentage growth rate of real per capita GDP. In addition we include the Heritage Foundation/Wall Street Journal "Index of Economic Freedom" (economic freedom) as a control. The index comprises various indicators of economic development such as government intervention in the economy, property rights, financial system development, etc. Time and country fixed effects are introduced in the regressions to capture other unobserved variables such as the quality of governance, the amount of corruption, etc.

As pointed out in section 3, interbank borrowing may be endogenous with respect to bank risk, e.g. if lending banks price risk or ration more risky banks. To deal with this possibility we perform a Durbin-Wu-Hausman test in order to empirically test for potential endogeneity. ${ }^{16}$ The results of the test confirm the existence of endogeneity. In this case simple panel OLS regressions will be biased and inconsistent.

In order to deal with the endogeneity of the interbank position we adopt an instrumental variables approach. An effective instrument for the net interbank position of a bank should be closely correlated with a bank's incentives to borrow in the interbank market but not simultaneously correlated with the bank's risk. We choose the ratio of a bank's retail deposits to its total loans (deposits/loans) as an instrument for its net interbank position. ${ }^{17}$ The retaildeposits to loans ratio is closely correlated with the bank's net interbank position, because in the sample countries a major determinant of interbank borrowing is the lack of well developed

\footnotetext{
${ }^{16}$ See Davidson and McKinnon (1993) for a description of the Durbin-Wu-Hausman test of endogeneity. We perform this test for all three specifications of the dependent variable. In each specification the endogeneity of the net interbank position was confirmed.

${ }^{17}$ Deposits/loans is a demand side instrument: the deposits/loans ratio is correlated with a bank's demand for interbank loans. An interesting robustness check would have been the inclusion of supply side instruments. Our dataset, however, does not provide us such instruments that are correlated with the supply for interbank loans faced by a bank but not with its risk.
} 
retail networks. If banks lack a wide-spread deposit gathering networks, they bear higher costs of deposit gathering and have stringer incentives to demand interbank financing. For banks with developed deposit gathering networks the incentives to borrow in the interbank market are weaker, because the cost advantage of interbank financing as compared to retail deposits is smaller. ${ }^{18}$

Moreover, we argue that the deposits-to-loans ratio is exogenous with regard to bank risk. Although it could be argued (as in Billet, Garfinkel and O’Neal, 1998) that a riskier bank can shift liabilities from uninsured wholesale funds to insured retail deposits, we consider such a shift extremely unlikely in the short-run due to the absence of sufficient deposit gathering networks. Nevertheless, as a robustness check we also present the results of the estimations when the lagged-retail-deposit-to-loans ratio (lagged deposits/lagged loans) is used as an instrument. $^{19}$

We apply a two-stage instrumental variable panel data estimator ${ }^{20}$ to estimate the impact of the interbank position on the three measures of banks risk using the deposits to loans ratio as an instrument. The results of the regressions are presented in Table 5.

The coefficients of the net interbank position in all regression specifications are positive and statistically significant. Thus, interbank borrowing, which implies negative net interbank assets, is associated with a lower level of risk taking. Banks borrowing on the interbank market have on average lower LLR, LLP and NCO ratios than banks which do not borrow in the interbank market. Moreover, results are economically significant. For example, a change in the interbank position (NIA/TA) from zero to minus 0.1 is associated with a drop in the ratio of loan loss reserves to gross loans of almost $48 \%$. Similarly, the ratio of loan loss

\footnotetext{
${ }^{18}$ The so called Stock and Watson rule of thumb (Stock and Watson, 2003) is often used as a proxy for the strength of an instrument. According to this rule the first stage F-statistics testing the hypothesis that the coefficients on the instruments are jointly zero should be at least 10 . In the case of the regression presented in Table 5 we have a F-statistics of 19.5 for the deposits/loans instrument.

${ }^{19}$ In this case the F-statistics for the Stock and Watson rule of thumb is 15.4

${ }^{20}$ We use the STATA two-stage GLS estimator with adjusted standard errors.
} 
provisions to gross loans drops by $48 \%$ and the ratio of net charge-offs to equity drops by $51 \%$.

\section{Control variables}

Bank size and bank size squared are both significant in all regression specifications. The coefficients suggest a nonlinear (U-shaped) relation between bank size and risk. Equity to total assets has a significant negative impact on the risk measures, which is consistent with the theoretical notion that banks with higher proportion of own capital invest in less risky projects. The foreign ownership dummy has significant negative coefficients in all regression specifications, presenting evidence for lower levels of risk undertaking by banks owned by foreign entities. This result supports similar findings in the literature on foreign bank entry in transition and developing countries (Clarke et al, 2003).

Concerning the macroeconomic variables, inflation does not have a significant impact on risk; per capita $G D P$ has a positive and statistically significant coefficient in the $L L P$ regression and a negative coefficient in the $N C O$ regression. GDP growth significantly reduces bank risk as measured by $L L R$ and $L L P$, indicating the cyclical impact on bank risk. The economic freedom index (which is decreasing with economic liberalization) enters the $L L R$ and $L L P$ regression specifications with a positive significant coefficient indicating that banks in less economically developed countries have riskier loan portfolios.

\section{Robustness checks and alternative specifications}

In this section we examine the robustness of the baseline instrumental variable estimation presented above by estimating alternative specifications of the instrumental variables. We start by replacing the deposits to loans ratio by the lagged deposits to loans ratio as an instrument. This specification addresses the potential critique that the deposits to loans ratio may not be exogenous if small banks are able to quickly shift their liabilities from the interbank to the retail deposit market. The results of this specification are presented in Table 6a. In addition we estimate the model by including both the deposit to loans ratio and the 
lagged deposits to lagged loans ratio as an instrument. In this case the number of instruments exceeds the number of endogenous variables and an overidentification restrictions test allows us to check the exogeneity of the instruments ${ }^{21}$. The results of these regression specifications are presented in Table $6 \mathrm{~b}$.

Alternatively, we include the deposits to loans ratio, the net interbank assets of large banks, the net interbank assets of small banks (for each country and year) and their interaction with the deposits to loans ratio as instruments. In this specification we enrich the set of instruments by inclusion of the banking system structure. The intuition is that the features of the banking system might influence the demand for interbank funds. So, for example, small banks operating in two-tier systems may anticipate that interbank borrowing is easier for low risk banks and adjust their risk levels accordingly. The results are presented in Table $6 c^{22}$

A comparison between the results in Tables $6 a$ to $6 \mathrm{c}$ shows that results are robust to changes in the instrument specification. For all regression specifications we are able to document lower risk of the interbank borrowing banks.

\section{Conclusion}

Existing empirical research on the relationship between interbank borrowing and bank risk is very limited and has found only marginal effects (Furfine, 2001; Ashcraft and Bleakley, 2006). One possible explanation is that interbank exposures in the countries which have been the focus of previous studies are with very short-term maturity (overnight). In addition the interbank borrowing banks in developed financial systems (and the US in particular) are the largest banks so that too-big-to-fail considerations reduce the lenders' incentives to control for borrower's risk.

\footnotetext{
${ }^{21}$ Deposits/loans and lagged deposits/lagged loans pass the overidentification restriction tests for all three dependent variables. The values of the $\chi^{2}$ statistics for the Sargan-Hansen tests are $0.068,0.533$ and 1.605 for $L L R, L L P$ and NCO, which correspond to p-values of $0.79,0.46$ and 0.21 , respectively.

${ }^{22}$ The overidentification reestriction tests are again passed in all but the $L L P$ regression specifications. The values of the $\chi^{2}$ statistics for the Sargan-Hansen tests are 4.747, 8.838 and 1.911 for LLR, LLP and NCO and correspond to $\mathrm{p}$-values of $0.18,0.03$ and 0.59 , respectively.
} 
In this paper, we use a novel dataset characterized by long-term interbank exposures and small size of the interbank borrowing banks to shed new light on the issue. We estimate the relationship between interbank borrowing and bank risk using a set of instrumental variables to control for the potential endogeneity of the interbank position with respect to the risk of a bank. Our results show that interbank borrowing is associated with substantially lower risk taking by the borrowing banks. These results are consistent with monitoring by the lending banks. 
Literature: 


\section{Literature:}

Allen, Franklin, and Douglas Gale. (2000) "Financial Contagion." Journal of Political Economy, 108(1),1-33.

Ashcraft, Adam B. (forthcoming) "Does the Market Discipline Banks? New Evidence from the Regulatory Capital Mix.” Journal of Financial Intermediation.

Ashcraft, Adam B., and Hoyt Bleakley. (2006) "On the Market Discipline of InformationallyOpaque Firms: Evidence from Bank Borrowers in the Federal Funds Market.” Federal Reserve Bank of New York Staff Reports 257.

Berger, Allen N. (1991) "Market Discipline in Banking." Proceedings of a Conference on Bank Structure and Competition, Federal Reserve Bank of Chicago.

Berger, Allen N., Nathan H. Miller, Mitchell A. Petersen, Raghuran G. Rajan, and Jeremy C. Stein. (2005) "Does function follow organizational form? Evidence from the lending practices of large and small banks.” Journal of Financial Economics, 76(2), 237-269.

Bhattacharya, Sudipto, and Douglas Gale. (1987) "Preference Shocks, Liquidity and Central Bank Policy." New Approaches to Monetary Economics. Cambridge: Cambridge University Press.

Billett, Matthew T., and Jon A. Garfinkel. (2004) "Financial Flexibility and the Cost of External Finance for U.S. Bank Holding Companies." Journal of Money, Credit and Banking, 36(5), 827-852.

Billet, Matthew T., Jon A. Garfinkel, and Edward S. O’Neal. (1998) “The Cost of Market versus Regulatory Discipline in Banking." Journal of Financial Economics, 48(3), 333358.

Bonin, John, Kalman Mizsei, Istvan Szekely, and Paul Wachtel. (1998) "Banking in Transition Economies: Developing Market Oriented Sectors in Eastern Europe.” Institute for EastWest Studies. 
Calomiris, Charles. (1998) "Blueprints for a New Global Financial Architecture.” American Enterprise Institute, Washington, DC.

Clarke, George R. G., Robert Cull, Maria S. Martinez Peria, and Susanna M. Sanchez (2003): “Foreign Bank Entry: Experience, Implications for Developing Economies, and Agenda for Further Research.” The World Bank Research Observer, 18 (1), 25-59.

Cole, David, and Betty F. Slade. (1996) "Building a Modern Financial System: The Indonesian Experience." Cambridge: Cambridge University Press.

Davidson, Russell, and James G. MacKinnon. (1993) "Estimation and Inference in Econometrics." New York, Oxford University Press.

Dinger, Valeriya, and Jürgen von Hagen. (2005) “The Competitive Advantage of Incumbents: Evidence from newly liberalized banking industries." mimeo.

Evanoff, Douglas D., and Larry D. Wall. (2001) "Sub-Debt Yield Spreads as Bank Risk Measures.” Journal of Financial Services Research, 20(2/3), 121-145.

Flannery, Mark, and Stanislava Nikolova. (2004) "Market Discipline of U.S. Financial Firms: Recent Evidence and Research Issues." Market Discipline across Countries and Industries, Cambridge: MIT Press.

Freixas, Xavier, Bruno Parigi, and Jean-Charles Rochet. (2000) "Systemic Risk, Interbank Relations and Liquidity Provisions by the Central Bank.” Journal of Money Banking and Credit, 32(3), 611-638.

Freixas, Xavier, and Jean-Charles Rochet. (1997) "Microeconomics of Banking." Cambridge: MITPress.

Furfine, Craig H. (2001) "Banks as Monitors of Other Banks: Evidence from the Overnight Federal Funds Market.” The Journal of Business, 74(1), 33-57.

Galmes, Sofia, and Maria C. Manzano. (1995) “El Mercado Interbancario de Depositos y las Entidades de Credito.” Boletín Economico del Banco de Espana, Febrero 1995. 
González-Hermosillo, Brenda. (1996) "Banking Sector Fragility and Systemic Sources of Fragility.” IMF Working Paper, 96/12.

King, Thomas B. (forthcoming) "Discipline and Liquidity in the Market for Federal Funds." Journal of Money, Banking and Credit.

Martin, Daniel. (1977) "Early Warnings of Bank Failure. A Logit Regression Approach.” Journal of Banking and Finance, 1(3), 249-276.

Morgan, Donald P., and Kevin J. Stiroh. (2001) "Market Discipline of Banks: The Asset Test.” Journal of Financial Services Research, 20(2/3), 195-208.

Nenovsky, Nikolay, and Kalina Dimitrova. (2003) "Deposit Insurance During EU Accession.” William Davidson Institute Working Paper Number 617.

Rochet, Jean-Charles, and Jean Tirole. (1996) "Interbank Lending and Systemic Risk." Journal of Money, Credit and Banking, 28(4), 733-762.

Sironi, Andrea. (2002) “Strengthening Banks' Market Discipline and Levelling the Playing Field: Are the Two Compatible?" Journal of Banking and Finance, 26(5), 1065-1091.

Stock, James H., and Mark W. Watson. (2003) "Introduction to Econometrics.” Boston, MA: Addison-Wesley. 
Table 1: Deposit market shares of major CEE banks

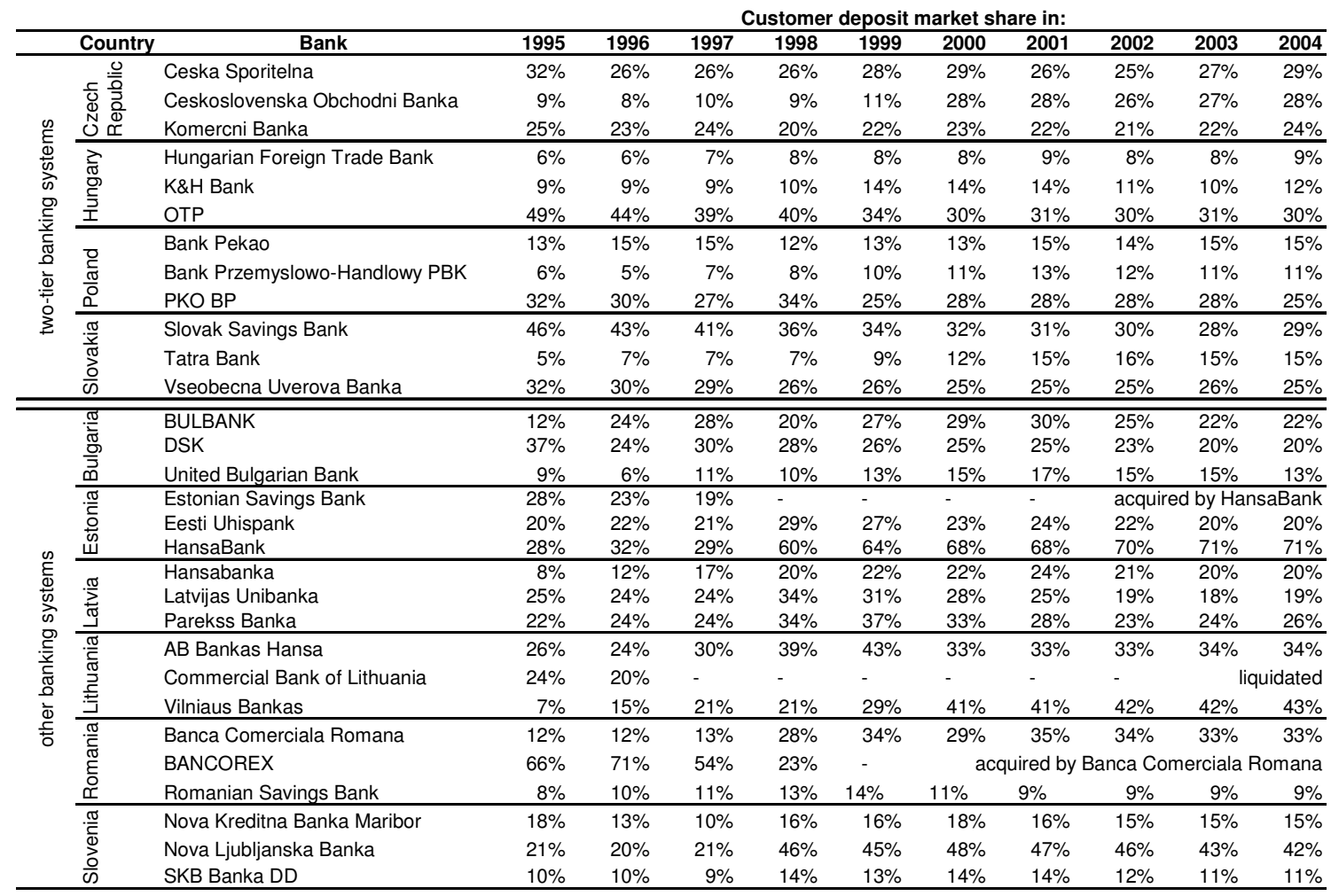

Source: Own calculations based on Bankscope 
Table 2: Large banks' interbank position

\begin{tabular}{|c|c|c|c|c|c|c|c|c|c|c|c|}
\hline & & 1995 & 1996 & 1997 & 1998 & 1999 & 2000 & 2001 & 2002 & 2003 & 2004 \\
\hline \multirow{4}{*}{ 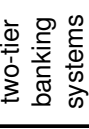 } & Czech Republic & 0.13 & 0.06 & 0.16 & 0.20 & 0.34 & 0.53 & 0.51 & 0.45 & 0.30 & 0.30 \\
\hline & Hungary & 0.02 & 0.22 & 0.10 & 0.14 & 0.15 & 0.11 & 0.17 & 0.25 & 0.12 & 0.15 \\
\hline & Poland & 0.10 & 0.10 & 0.09 & 0.07 & 0.08 & 0.10 & 0.12 & 0.12 & 0.10 & 0.17 \\
\hline & Slovakia & 0.15 & 0.09 & 0.07 & 0.06 & 0.11 & 0.12 & 0.17 & 0.33 & 0.10 & 0.19 \\
\hline \multirow{6}{*}{ 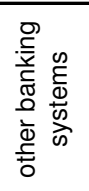 } & Bulgaria & 0.17 & -0.50 & 0.29 & 0.47 & 0.44 & 0.66 & 0.49 & 0.42 & 0.36 & 0.33 \\
\hline & Estonia & 0.20 & 0.00 & -0.14 & -0.12 & -0.13 & -0.05 & 0.06 & -0.05 & -0.05 & -0.02 \\
\hline & Latvia & 0.12 & 0.13 & 0.09 & -0.11 & 0.00 & 0.07 & -0.09 & -0.05 & -0.15 & -0.17 \\
\hline & Lithuania & 0.04 & 0.00 & 0.01 & -0.04 & -0.03 & 0.09 & 0.09 & -0.13 & -0.29 & -0.20 \\
\hline & Romania & 0.35 & -0.27 & -0.61 & 0.08 & -0.07 & 0.07 & 0.06 & 0.00 & -0.04 & -0.14 \\
\hline & Slovenia & 0.26 & 0.24 & 0.10 & -0.02 & -0.04 & -0.07 & -0.11 & 0.02 & 0.33 & 0.27 \\
\hline
\end{tabular}

Note: Large banks interbank position is computed as the ratio: $\frac{\sum_{1}^{n} I A_{-} L B_{i}-\sum_{1}^{n} I L_{-} L B_{i}}{\sum_{1}^{n} C D_{-} L B_{i}}$,

$n \in(1,3)$ depending on country and year, where $I A_{-} L B_{i}$ denotes the amount of interbank assets of i-th large bank in the respective country and year; $I L_{-} L B_{i}$ denotes the interbank liabilities of this bank and $C D_{-} L B_{i}$ denotes the amount of its customer deposits.

Source: Own calculations based on Bankscope 
Table 3: Small banks' interbank position

\begin{tabular}{|c|c|c|c|c|c|c|c|c|c|c|c|}
\hline & & 1995 & 1996 & 1997 & 1998 & 1999 & 2000 & 2001 & 2002 & 2003 & 2004 \\
\hline \multirow{4}{*}{ 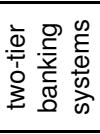 } & Czech Republic & -0.33 & -0.31 & -0.22 & -0.09 & -0.04 & -0.05 & -0.12 & -0.07 & -0.01 & 0.05 \\
\hline & Hungary & -0.26 & -0.17 & -0.25 & -0.17 & -0.11 & -0.12 & -0.07 & -0.10 & -0.17 & -0.19 \\
\hline & Poland & -0.11 & -0.19 & -0.08 & -0.19 & -0.11 & -0.04 & -0.06 & 0.00 & -0.03 & 0.07 \\
\hline & Slovakia & -0.34 & -0.29 & -0.36 & -0.30 & -0.32 & -0.07 & -0.01 & -0.08 & -0.12 & -0.14 \\
\hline \multirow{6}{*}{ 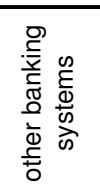 } & Bulgaria & -0.24 & 1.60 & 1.03 & 0.76 & 0.73 & 0.76 & 0.66 & 0.27 & 0.13 & 0.10 \\
\hline & Estonia & 0.10 & 0.03 & -0.16 & -0.25 & -0.09 & 0.22 & 0.07 & -0.58 & -0.61 & -0.20 \\
\hline & Latvia & 1.10 & 1.56 & 1.02 & 0.16 & 0.38 & 1.08 & 0.83 & 1.02 & 0.72 & 0.65 \\
\hline & Lithuania & -0.17 & 0.04 & 0.27 & -0.05 & -0.03 & -0.06 & 0.00 & -0.19 & -0.19 & -0.13 \\
\hline & Romania & 0.18 & 0.11 & 0.52 & 0.33 & 0.32 & 0.03 & 0.37 & 0.12 & -0.08 & -0.12 \\
\hline & Slovenia & 0.10 & 0.17 & 0.07 & 0.07 & 0.01 & 0.05 & 0.05 & -0.08 & -0.17 & -0.17 \\
\hline
\end{tabular}

Note: Small banks interbank position is computed as the ratio: $\frac{\sum_{1}^{m} I A_{-} S B_{j}-\sum_{1}^{m} I L_{-} S B_{j}}{\sum_{1}^{m} L_{-} S B_{j}}$, $m \in(4,47)$ where $I A_{-} S B_{j}$ denotes the amount of interbank assets of $j$-th small bank in the respective country and year; $I L_{-} S B_{j}$ denotes the interbank liabilities of this bank and $L_{-} S B_{j}$ denotes the amount of its loans to non-financial institutions.

Source: Own calculations based on Bankscope 
Table 4: Summary statistics

\begin{tabular}{lrrrrr}
\hline & $\begin{array}{r}\text { Number of } \\
\text { observations }\end{array}$ & Mean & $\begin{array}{r}\text { Standard } \\
\text { deviation }\end{array}$ & Minimum & Maximum \\
\hline loan loss reserves to gross loans & 1468 & 8.216 & 11.837 & 0.011 & 98.151 \\
loan loss provisions to gross loans & 1459 & 0.168 & 2.216 & 0.000 & 74.873 \\
net charge-offs to equity & 377 & 3.407 & 7.324 & 0.001 & 85.366 \\
net interbank assets to total assets & 1989 & 0.020 & 0.268 & -2.602 & 0.924 \\
retail deposits to loans & 1973 & 1.573 & 1.299 & 0.000 & 9.989 \\
size & 2092 & 1287 & 2831 & 1 & 29700 \\
equity to total assets & 2092 & 0.139 & 0.153 & -0.319 & 1.000 \\
\hline
\end{tabular}

Note: Loan loss reserves to gross loans are computed as (loan loss reserves/gross loans). Loan loss provisions to gross loans are computed as (loan loss provisions/gross loans). Net-charge-offs to equity are defined as (net charge-offs/equity). Net interbank assets to total assets is equal to (interbank assets - interbank liabilities)/total assets. Retail deposits to loans is equal to (total deposits - interbank deposits)/loans. Size is equal to total asset in million USD. Equity to total assets is (equity/total assets).

Source: Own calculations based on Bankscope 
Table 5: Interbank position and bank risk

Panel data instrumental variable estimation: net interbank assets to total assets are instrumented by the ratio of retail deposits to loans

\begin{tabular}{|c|c|c|c|}
\hline & LLR & LLP & NCO \\
\hline \multirow[t]{2}{*}{ net interbank asset/total assets } & 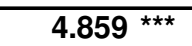 & $4.823^{\star \star \star}$ & 5.124 \\
\hline & 1.153 & 0.960 & 3.321 \\
\hline \multirow[t]{2}{*}{ size } & $-3.276 * \star \star$ & $-2.538 * \star \star$ & -3.783 ** \\
\hline & 0.513 & 0.620 & 1.499 \\
\hline \multirow[t]{2}{*}{ size2 } & $0.125 * \star \star$ & $0.084 * \star *$ & 0.112 * \\
\hline & 0.020 & 0.024 & 0.058 \\
\hline \multirow[t]{2}{*}{ equity/total assets } & $-0.049 * \star \star$ & $-0.042 * \star *$ & $-0.045 *$ \\
\hline & 0.010 & 0.008 & 0.025 \\
\hline \multirow[t]{2}{*}{ foreign } & $-0.322 * \star$ & $-0.494 * \star \star$ & -0.646 ** \\
\hline & 0.137 & 0.145 & 0.276 \\
\hline \multirow{2}{*}{ net interbank assets_large banks } & 0.328 & -0.697 & -0.249 \\
\hline & 0.318 & 0.464 & 1.115 \\
\hline \multirow[t]{2}{*}{ net interbank assets_small banks } & -0.274 & -0.360 & -1.015 \\
\hline & 0.265 & 0.342 & 0.939 \\
\hline \multirow[t]{2}{*}{ inflation } & 0.000 & 0.078 & 0.038 \\
\hline & 0.044 & 0.062 & 0.204 \\
\hline \multirow[t]{2}{*}{ per capita GDP } & 0.146 & $0.811^{\star * \star}$ & -0.977 * \\
\hline & 0.122 & 0.257 & 0.516 \\
\hline \multirow[t]{2}{*}{ GDP growth } & $-4.037 * *$ & $-5.564 *$ & 0.149 \\
\hline & 1.966 & 2.889 & 5.894 \\
\hline \multirow[t]{2}{*}{ economic freedom } & 0.524 ** & $0.831 * *$ & 0.971 \\
\hline & 0.212 & 0.342 & 0.646 \\
\hline \multirow[t]{2}{*}{ constant } & $21.192 * \star \star$ & 5.199 & 20.008 * \\
\hline & 3.759 & 5.157 & 11.725 \\
\hline number of observations & 1129 & 1132 & 284 \\
\hline R-squared & 0.110 & 0.494 & 0.667 \\
\hline
\end{tabular}

Note: Coefficients in bold, standard errors below coefficients. *,**,*** indicate significance at the $10 \%, 5 \%$ and $1 \%$ level, respectively. 
Table 6: Interbank position and bank risk: alternative instruments

a. Panel data instrumental variable estimation: net interbank assets to total assets are instrumented by the ratio of lagged retail deposits to lagged loans

\begin{tabular}{|c|c|c|c|}
\hline & LLR & LLP & NCO \\
\hline \multirow[t]{2}{*}{ net interbank asset/total assets } & 5.776 * & 3.182 ** & 22.388 \\
\hline & 3.370 & 1.458 & 21.189 \\
\hline \multirow[t]{2}{*}{ size } & $-3.634 * \star \star$ & $-2.570 * \star \star$ & -4.791 \\
\hline & 0.819 & 0.699 & 3.727 \\
\hline \multirow[t]{2}{*}{ size2 } & $0.138 * \star *$ & $0.087^{\star \star *}$ & 0.150 \\
\hline & 0.030 & 0.026 & 0.144 \\
\hline \multirow[t]{2}{*}{ equity/total assets } & $-0.054 * \star$ & $-0.029 * \star \star$ & -0.153 \\
\hline & 0.026 & 0.011 & 0.141 \\
\hline \multirow[t]{2}{*}{ foreign } & -0.299 & $-0.571 * \star \star$ & -0.178 \\
\hline & 0.217 & 0.134 & 0.831 \\
\hline \multirow{2}{*}{ net interbank assets_large banks } & 0.093 & -0.642 & -0.406 \\
\hline & 0.421 & 0.473 & 2.529 \\
\hline \multirow[t]{2}{*}{ net interbank assets_small banks } & -0.352 & -0.022 & -3.743 \\
\hline & 0.541 & 0.380 & 3.862 \\
\hline \multirow[t]{2}{*}{ inflation } & 0.025 & 0.067 & 0.282 \\
\hline & 0.050 & 0.066 & 0.506 \\
\hline \multirow[t]{2}{*}{ per capita GDP } & 0.198 & $0.883^{* * *}$ & -0.921 \\
\hline & 0.134 & 0.251 & 0.999 \\
\hline \multirow[t]{2}{*}{ GDP growth } & -3.775 & $-6.533 * \star$ & 4.657 \\
\hline & 2.350 & 2.872 & 14.802 \\
\hline \multirow[t]{2}{*}{ economic freedom } & 0.419 & 0.361 & 2.108 \\
\hline & 0.232 & 0.335 & 1.754 \\
\hline \multirow[t]{2}{*}{ constant } & 23.616 *** & 6.062 & 25.042 \\
\hline & 6.015 & 5.471 & 26.843 \\
\hline number of observations & 1043 & 1037 & 272 \\
\hline R-squared & 0.101 & 0.625 & 0.3 \\
\hline
\end{tabular}

Note: Coefficients in bold, standard errors below coefficients. *,**,*** indicate significance at the $10 \%, 5 \%$ and $1 \%$ level, respectively 
b. Panel data instrumental variable estimation: net interbank assets to total assets are instrumented by the ratio of retail deposits to loans and the ratio of lagged retail deposits to lagged loans*

\begin{tabular}{|c|c|c|c|}
\hline & LLR & LLP & NCO \\
\hline \multirow[t]{2}{*}{ net interbank asset/total assets } & $5.100^{\star \star \star}$ & $4.785 * \star \star$ & $4.781^{\star \star}$ \\
\hline & 1.269 & 1.028 & 2.501 \\
\hline \multirow[t]{2}{*}{ size } & $-3.473 * \star *$ & $-2.604^{\star \star *}$ & -3.112 ** \\
\hline & 0.581 & 0.745 & 1.391 \\
\hline \multirow[t]{2}{*}{ size2 } & $0.130 * * *$ & $0.086 * * *$ & 0.089 * \\
\hline & 0.022 & 0.028 & 0.053 \\
\hline \multirow[t]{2}{*}{ equity/total assets } & $-0.049 * \star \star$ & $-0.044 * \star \star$ & $-0.031 *$ \\
\hline & 0.010 & 0.009 & 0.019 \\
\hline \multirow[t]{2}{*}{ foreign } & -0.291 * & $-0.508 * \star \star$ & $-0.625 * *$ \\
\hline & 0.155 & 0.164 & 0.247 \\
\hline \multirow[t]{2}{*}{ net interbank assets_large banks } & 0.144 & -0.705 & -0.706 \\
\hline & 0.317 & 0.482 & 1.377 \\
\hline \multirow[t]{2}{*}{ net interbank assets_small banks } & -0.239 & -0.171 & -0.782 \\
\hline & 0.260 & 0.347 & 0.938 \\
\hline \multirow[t]{2}{*}{ inflation } & 0.020 & 0.001 & -0.014 \\
\hline & 0.044 & 0.001 & 0.209 \\
\hline \multirow[t]{2}{*}{ per capita GDP } & 0.197 & $0.863^{* \star \star}$ & $-0.969 *$ \\
\hline & 0.131 & 0.258 & 0.519 \\
\hline \multirow[t]{2}{*}{ GDP growth } & $-4.690 \star \star$ & $-6.247 * \star$ & 0.099 \\
\hline & 1.861 & 2.977 & 6.690 \\
\hline \multirow{2}{*}{ economic freedom } & $0.456 * \star$ & 0.439 & 1.121 \\
\hline & 0.208 & 0.346 & 0.686 \\
\hline \multirow[t]{2}{*}{ constant } & $22.571^{\star \star \star}$ & 6.732 & 14.197 \\
\hline & 4.132 & 5.792 & 11.190 \\
\hline number of observations & 1043 & 1037 & 272 \\
\hline R-squared & 0.112 & 0.584 & 0.731 \\
\hline
\end{tabular}

Note: Coefficients in bold, standard errors below coefficients. *,**,*** indicate significance at the $10 \%, 5 \%$ and $1 \%$ level, respectively

* Overidentification restriction tests are passed for all three regression specifications 
c. Panel data instrumental variable estimation: net interbank assets to total assets are instrumented by the ratio of retail deposit to loans, net interbank assets of large banks ( banks (nia_sb) and the interactions nia_sb*(deposits/loans) and nia_lb*(deposits/loans)*

\begin{tabular}{|c|c|c|c|}
\hline & LLR & LLP & NCO \\
\hline \multirow[t]{2}{*}{ net interbank asset/total assets } & $3.230 * \star \star$ & $4.024^{\star \star \star}$ & $2.801^{\star}$ \\
\hline & 0.599 & 0.759 & 1.554 \\
\hline \multirow[t]{2}{*}{ size } & $-2.951 * \star *$ & $-2.090 * \star *$ & -3.614 ** \\
\hline & 0.403 & 0.589 & 1.511 \\
\hline \multirow[t]{2}{*}{ size2 } & $0.111^{\star \star *}$ & $0.067^{* * *}$ & 0.103 * \\
\hline & 0.016 & 0.023 & 0.058 \\
\hline \multirow[t]{2}{*}{ equity/total assets } & $-0.035 * \star \star$ & $-0.038 * \star \star$ & -0.037 * \\
\hline & 0.006 & 0.007 & 0.021 \\
\hline \multirow[t]{2}{*}{ foreign } & $-0.338^{* * *}$ & $-0.531^{\star \star \star *}$ & -0.678 ** \\
\hline & 0.127 & 0.150 & 0.283 \\
\hline \multirow{2}{*}{ inflation } & -0.010 & 0.069 & 0.000 \\
\hline & 0.034 & 0.057 & 0.185 \\
\hline \multirow[t]{2}{*}{ per capita GDP } & 0.086 & $0.846 * \star *$ & -0.896 * \\
\hline & 0.113 & 0.236 & 0.485 \\
\hline \multirow[t]{2}{*}{ GDP growth } & $-5.019 * \star \star$ & -5.917 ** & -0.273 \\
\hline & 1.479 & 2.507 & 5.422 \\
\hline \multirow[t]{2}{*}{ economic freedom } & $0.547^{\star \star *}$ & $0.737 * \star$ & 0.751 \\
\hline & 0.169 & 0.314 & 0.590 \\
\hline \multirow[t]{2}{*}{ constant } & $19.515 * \star *$ & 2.191 & 18.881 \\
\hline & 2.947 & 4.810 & 11.631 \\
\hline number of observations & 1129 & 1132 & 284 \\
\hline R-squared & 0.149 & 0.548 & 0.731 \\
\hline
\end{tabular}

Note: Coefficients in bold, standard errors below coefficients. *,**,*** indicate significance at the $10 \%, 5 \%$ and $1 \%$ level, respectively

* Overidentification restriction tests are passed for all but the $L L P$ regression specifications 